\title{
Siirt İli Tillo Tabiat Parkı'nın Kullanıcı Memnuniyeti Açısından Değerlendirilmesi
}

\author{
Arzu Altuntaş ${ }^{1 *}$ \\ ${ }^{1}$ Siirt Üniversitesi, Ziraat Fakültesi, Peyzaj Mimarlığı Bölümü, Siirt, Türkiye (ORCID: 0000-0003-1258-3875)
}

(Illk Geliş Tarihi 17 Ocak 2020 ve Kabul Tarihi 29 Şubat 2020)

(DOI: $10.31590 /$ ejosat.690258)

ATIF/REFERENCE: Altuntaş, A., (2020). Tillo Tabiat Parkı'nın Kullanıcı Memnuniyeti Açısından Değerlendirilmesi. Avrupa Bilim ve Teknoloji Dergisi, (18), 359-367.

$\ddot{O} \mathbf{z}$

Yaşam koşullarının giderek zorlaşması insanların rekreasyon ihtiyaçlarının artmasının en önemli sebeplerinden biri olarak sayılmaktadır. Özellikle şehirlerde yaşayan kişiler, bu ihtiyaçlarını giderebilmek için kısa süreli de olsa yakın çevrelerindeki doğal alanları tercih etme eğilimindedirler. Bu nedenle özellikle kent içinde ve kent yakın çevresinde bulunan mesire alanları, kent ormanları ve tabiat parkları en çok ziyaret edilen doğal alanlar arasında yer almaktadır.

Kent içinde ve yakın çevresinde bulunan doğal alanlar insanlara hem dinlenme ve manzara izleme imkanları sunmakta ve hem de alanın özelliklerine göre piknik yapma, kuş gözlemciliği, fotoğraf̧̧ılık, dağcılık, kaya tırmanışı gibi farklı aktivitelerin yapılmasına olanak tanımaktadır. Bu tür rekreasyonel aktivitelerde, alanın sahip olduğu özellikler ve kullanıcı memnuniyeti ziyaret sıklığı ile yoğunluğunu etkilemekte, kişilerin alan seçimlerinde yol gösterici olmaktadır. Bir alanın doğal özellikleri ya da alanda yapılabilecek aktivite sayısı ne kadar fazlaysa o alanın kullanıcı sayısı da o oranda artmaktadır. Çoğu durumda ise insanlar yaşadıkları yere en yakın olan alanı tercih etme eğilimi göstermektedir.

Bu çalışmada Siirt ili Tillo ilçesinde yer alan Tillo Tabiat Parkı kullanıcı memnuniyetinin değerlendirilmesi amaçlanmıştır. Tillo Tabiat Parkı, Siirt ilinde yer alan ve 2014 yılında ilan edilen tek tabiat parkı olup kent merkezine yaklaşık olarak 9 km uzaklıkta bulunmaktadır. Çalışma amacına göre arazi gözlemleri ve literatür taraması yapılmış; yöre halkına uygulanan anket sonuçları istatistiksel yöntemlerle analiz edilmiştir. Alan kullanıcıları için hazırlanan anket, \% 95 güven aralığında, 2018 yılı Haziran - Eylül dönemleri arasında tesadüfi yöntemle seçilen 100 kişiye yüz yüze görüşme şeklinde uygulanmıştır. Çıkan sonuçlara göre yöre halkı Tillo Tabiat Parkı'ndan genel anlamda memnuniyet duymaktadır. Park yöre halkı tarafından özellikle hafta sonu akşam saatlerinde sıklıkla tercih edilmektedir. Alanın uzun süreli güneş ışı̆̆ına maruz kalması ve gölgeleme ihtiyacının fazla olması gibi sebepler ise parkın kullanımını sınırlandıran etmenler olarak tespit edilmiştir.

Anahtar Kelimeler: Tabiat Parkı, Rekreasyon, Kullanıcı Memnuniyeti, Siirt, Tillo Tabiat Park1

\section{The Determination of User Satisfaction in Tillo Nature Park in Siirt}

\begin{abstract}
Increasingly difficult living conditions are considered as one of the most important reasons for the increase of recreational needs of people. Particularly in cities, people tend to prefer nearby natural areas, even if they have short time to meet these needs. For this reason, especially recreation areas, urban forests and nature parks in or near the cities are among the most visited natural areas.

The natural areas in and around the city offer people the opportunity to rest and enjoy the scenery. It also allows different activities such as picnic, bird watching, photography, mountaineering, rock climbing according to the characteristics of the area. In such
\end{abstract}

\footnotetext{
* Sorumlu Yazar: Siirt Üniversitesi, Ziraat Fakültesi, Peyzaj Mimarlığı Bölümü, Siirt, Türkiye, ORCID: 0000-0003-1258-3875, arzualtuntas@yahoo.com.tr
} 
recreational activities, the features of the area and user satisfaction affect the frequency and intensity of visits and it guides people for the selection of the area. The more natural features of an area or the number of activities that can be done in the area increases the number of users of that area. In most cases, people tend to prefer the area closest to where they live.

In this study, it was aimed to evaluate the user satisfaction of Tillo Nature Park in Tillo, Siirt. Tillo Nature Park is the only nature park in Siirt province that was announced in 2014 and is approximately $9 \mathrm{~km}$ from the city center. According to the purpose of study, field observations and literature searches were made. The questionnaire, prepared for the field users, was applied in a face-to-face interview to 100 people selected by random method between June and September 2018, with a 95\% confidence interval. The survey results applied to the local people were analyzed with statistical methods. According to the results, the locals are generally satisfied with Tillo Nature Park. The park is frequently preferred by local people, especially at the weekend evening hours. Reasons such as long-term exposure of the area to sunlight and high need for shading were determined as factors limiting the use of the park.

Keywords: Nature Park, Recreation, User Satisfaction, Siirt, Tillo Nature Park

\section{Giriş}

Nüfus artışı, teknolojideki yeni gelişmeler, iş gücü talebinin artması, sanayileşme ve göç gibi nedenler özellikle Endüstri Devrimi sonrası plansız ve hızla gelişen kentlerin oluşmasına sebep olmuştur. Tüm dünyada olduğu gibi ülkemizde de doğal alanlar yok edilmeye, peyzajda hızlı bir değişim yaşanmaya ve beton kentler oluşmaya başlamıştır. Bunun sonucu olarak, oluşan bu mekanlardaki baskılar, ulaşım ile ilgili problemler ve gün geçtikçe artan çevre sorunları gibi faktörler insan hayatını fiziksel, sosyal ve ruhsal açıdan tehdit etmektedir (Akten, 2003; Y1lmaz vd., 2009).

Özellikle, büyük şehirlerde ve bu alanlara yakın yerlerde görülen olumsuz etkiler, insanların rekreasyon ihtiyacını ve dolayısıyla da kentsel ve kent yakın çevrelerinde açık yeşil alan gereksinimini gündeme getirmiş; rekreasyonel planlamaların yapılması zorunluluğunu ortaya koymuştur (Kurum ve Odabaş 1991; Akten,2003).

Türk Dil Kurumu'na (2018) göre "rekreasyon” insanların boş zamanlarında, eğlence ve spor amacıyla gönüllü olarak katıldıkları etkinlikler anlamına gelmektedir. Akten (2003) rekreasyonun "re-tekrar" ve "create-yaratma" anlamına geldiğine ifade ederek, rekreasyonda önemli olanın insanların dinlenmesinin ve enerji toplamasının ana amaç olduğuna vurgu yapmaktadır.

Günümüzde insanlar artık yoğun şehirlerin kalabalığından uzakta, doğal alanların içinde rekreasyon ihtiyaçlarını karşılamak adına, kent çevrelerindeki kırsal alanlara, ormanlara ve korunan alanlara yönelmektedir. Ülkemiz yasal mevzuatında rekreasyonel faaliyetlere izin verilen korunan alanlar milli parklar, tabiat parkları ve orman içi dinlenme alanlarıdır.

"Milli park" ulusal ve uluslararası alanda, hem bilimsel hem de estetik açılardan ender doğal / kültürel özellikler ile rekreasyon ve turizm alanlarına sahip tabiat parçlarını; "tabiat parkı”, manzara bütünlügü de gözetilerek sahip olduğu bitki örtüsü ve yaban hayatı özellikleri ile halka rekreasyon olanakları sağlayan doğal alanları ifade etmektedir (Anonim, 1983). "Orman içi dinlenme alanı", bir diğer ifadeyle mesire yeri ise halkın rekreasyon ihtiyaçlarını karşılamak ve turistik faaliyetlere imkan vermek amacıyla genellikle günübirlik olarak kullanılan, gerekli tüm alt / üst yapıların tesis edildiği, estetik ve doğal değerlere sahip tabii ormanlık alanlardır (Anonim, 2013).

Bir alanın koruma altına alınması ve kullanılmasıyla ilgili birtakım kriterler ve koşullar bulunmaktadır. Resmi Gazete’nin 12.12.1986 tarih ve 19309 sayısında yayımlanan Milli Parklar Yönetmeliği'ne göre bir alanın tabiat parkı ilan edilebilmesi için aranan kriterler şunlardır (Anonim, 1986):

1 - Bölgesel ya da ulusal düzeyde doğal yapıya, bitki örtüsüne ve doğal yaşam özellikleri ile manzara güzelliği ile rekreasyon potansiyeline sahip olması

2 - Alan büyüklüğünün kaynak değerleri ve manzara bütünlüğü açısından yeterli büyüklükte olması

3 - Özellikle açık hava rekreasyonel faaliyetleri bakımında yüksek potansiyele sahip olması ve farklı aktivitelerin gerçekleştirilebilmesine olanak tanıması

4 - Yöresel yapıya uygun olması, örf, adet ve gelenekler ile arazi desenlerini ve kültürel manzaraları içermesi

5 - Mülkiyetinin devlete ait olması

Ülkemizde 2018 yılı itibariyle 42 adet milli park, 229 adet tabiat parkı ve çok sayıda orman içi dinlenme alanı bulunmaktadır (Doğa Koruma ve Milli Parklar Genel Müdürlüğü, 2018). Bu çalışmanın amacı Siirt ilinde yer alan tek tabiat parkı olan Tillo Tabiat Parkı'nın kullanıcı memnuniyetinin belirlenmesi ve peyzaj mimarlığı açısından değerlendirilmesidir.

\section{Materyal ve Metot}

\subsection{Materyal}

Siirt, Güneydoğu Anadolu Bölgesi’nde yer alan, 324.394 nüfuslu (TÜİK, 2017), doğal ve kültürel değerlere sahip bir ildir. İlin 7 adet ilçesi bulunmaktadır. Çalışmanın konusu olan Tillo Tabiat Parkı, merkez ilçeye $9 \mathrm{~km}$ mesafede bulunan Tillo (Aydınlar) ilçesinde yer almaktadır. İlçenin yüzölçümü yaklaşık olarak 6900 ha'dır. İlçe doğuda Pervari ve kuzeydoğuda Şirvan, batıda ise Siirt ili merkez ilçesiyle çevrilidir. $37^{\circ} 57^{\prime} 05^{\prime \prime}$ kuzey enlemleri ile $42^{\circ} 02^{\prime} 18^{\prime \prime}$ doğu boylamları arasında yer alan, 40,14 ha büyüklüğe sahip olan Tillo Tabiat Park1, 29.08.2014 tarih ve 18031414-401-1440 sayılı Bakanlık Oluru ile tabiat park1 olarak ilan edilmiştir (Anonim, 2015) 
(Şekil 1). Parka ait 2015 yılında T.C. Tarım ve Orman Bakanlı̆̆ı Doğa Koruma ve Milli Parklar Genel Müdürlüğü tarafından hazırlanan bir gelişme planı bulunmaktadır.

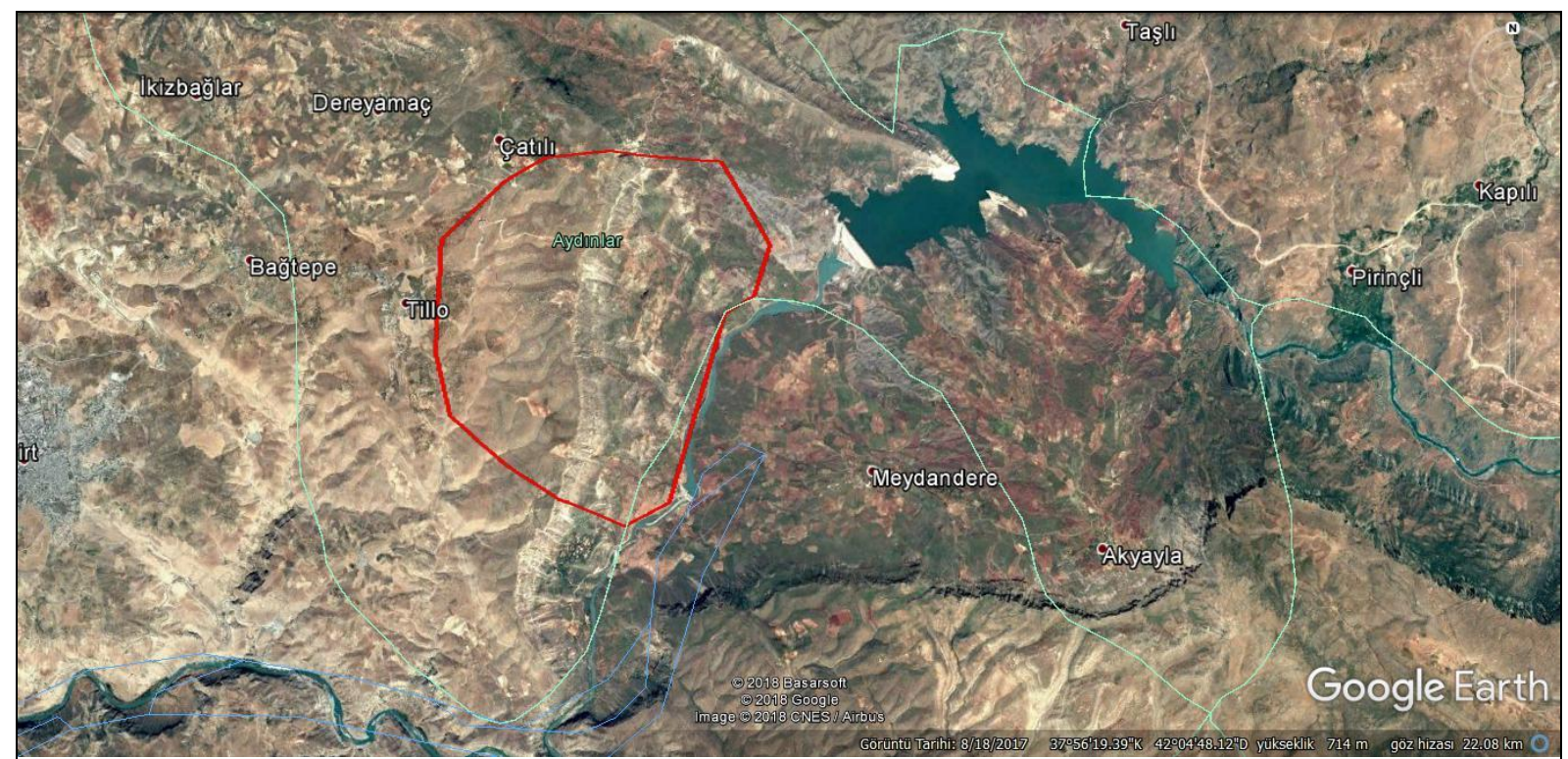

Şekil 1. Araştırma alanının coğrafi konumu

Tillo Tabiat Parkı doğusunda Botan Çayı, batısında Tillo ilçe merkezi, kuzeyinde Taşbalta köyü, güneyinde ise Kale Rekreasyon Alanı bulunmaktadır. Konumu itibariyle nispeten hareketli bir yapıya sahiptir. En yüksek noktası $1410 \mathrm{~m}$ ve en düşük noktası ise 1291 m'dir (Şekil 2).

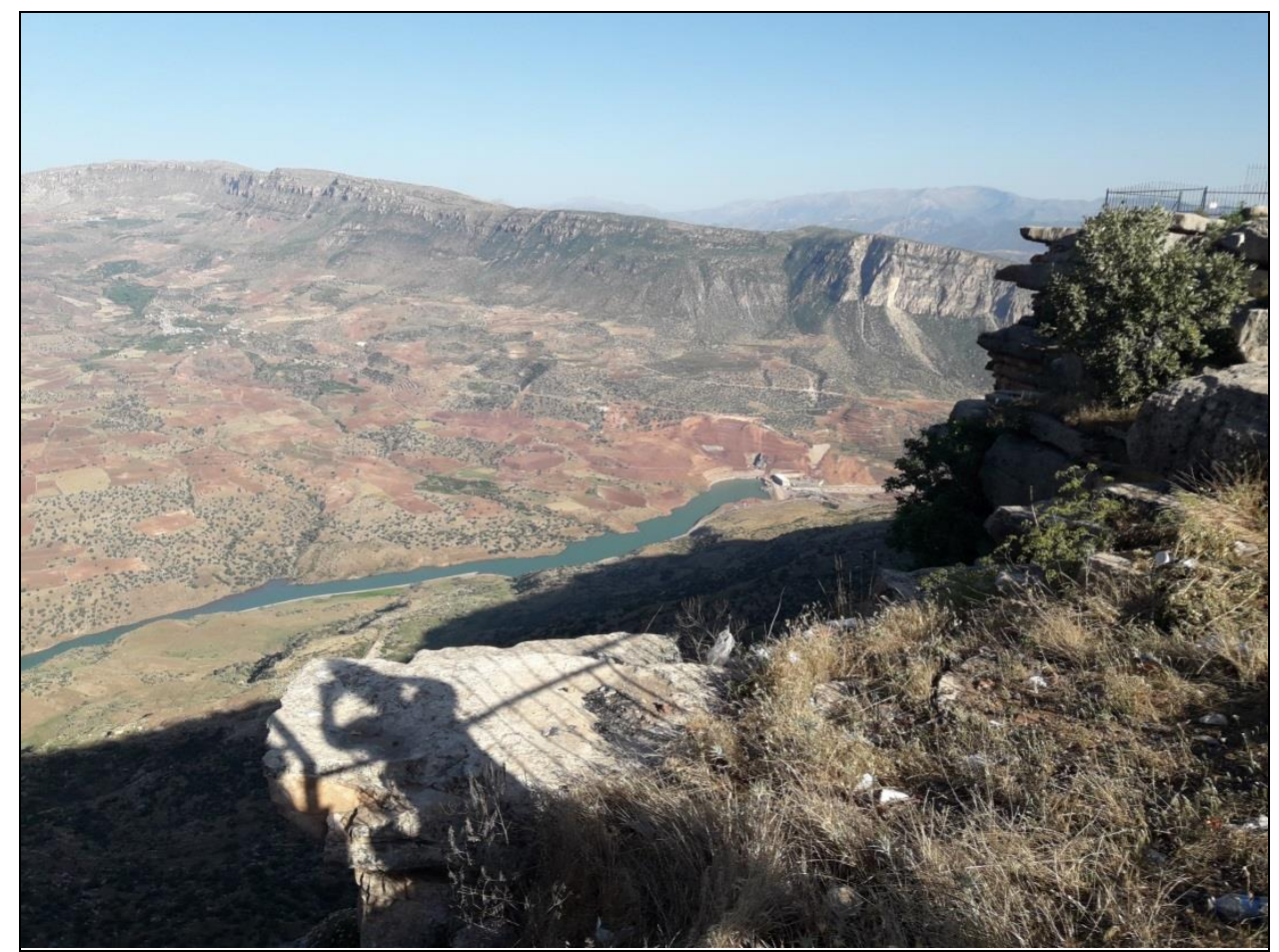

Şekil 2. Tillo Tabiat Parkı’ndan bir görünüş (Orijinal, 2018)

Ortalama sıcaklıklarda Ocak ayında en düşük değerler $\left(-15,6^{\circ} \mathrm{C}\right)$ ölçülürken; Ağustos ayında en yüksek değerler $\left(46,0^{\circ} \mathrm{C}\right)$ görülmektedir. En fazla yağış Mart ayında (104,4 mm), en az yă̆ı̧ ise Ağustos (1,0 mm) ayında gözlenmektedir. (Anonim, 2015).

Mevsimlik Bebil Deresi, parkın sınırları dışından doğup, parkın güneybatısından alana giren ve doğusundaki uçurumda sonlanan tek daimi deredir (Anonim, 2015). 
Tillo Tabiat Parkı, derinliği 0-20 cm arasında değişen VI. sınıf kahverengi orman topraklarından oluşmaktadır. Toprak derinliği çok sı̆̆ olduğundan dolayı şiddetli erozyon riski bulunmaktadır (Anonim, 2015).

Alanda insan etkisiyle bozulmuş bitki örtüsü bulunmaktadır. aşırı otlatma sonucunda antropojenik stepler oluşmuştur. En fazla görülen doğal bitki örtüsü türleri Quercus türleridir. Quercus brantii bu alandaki dominant tür konumundadır. Diğer türlerden bazıları Pistacia terebinthus, Crataegus monogyna, Astragalus gummifer, Teucrium sp., Verbascum sp, Scrophularia sp., Salvia sp., Bromus sp'dir (Anonim, 2015).

Fauna varlığı açısından gri leş kargası, dağ bülbülü, kurt ve tilki türlerine sık; engerek yılanı, kara kaplumbağası, dikenli keler, kertenkele, şahin, kartal ve kızıl akbaba türlerine ise seyrek oranlarda rastlanmaktadır (Anonim, 2015).

Biyolojik çeşitlilik ve kayaç oluşumları açısından Siirt ili için önemli doğal alanlardan biri olan ve kontrollü bir girişin (Şekil 3) bulunduğu Tillo Tabiat Parkı'nda idari ziyaretçi merkezi, kır lokantası (Şekil 4), cam seyir terası (Şekil 5), yöresel ürün satış birimleri, otoparklar, satış büfesi, çeşmeler, yaya ve araç yolları, barbekülü pergolalar, gölgelikli oturma birimleri (Şekil 6), çocuk oyun alanı, spor aletlerinin olduğu bir alan, mescit, tuvaletler, aydınlatma elemanları, çöp kutuları bulunmaktadır (Altuntaş, 2018).

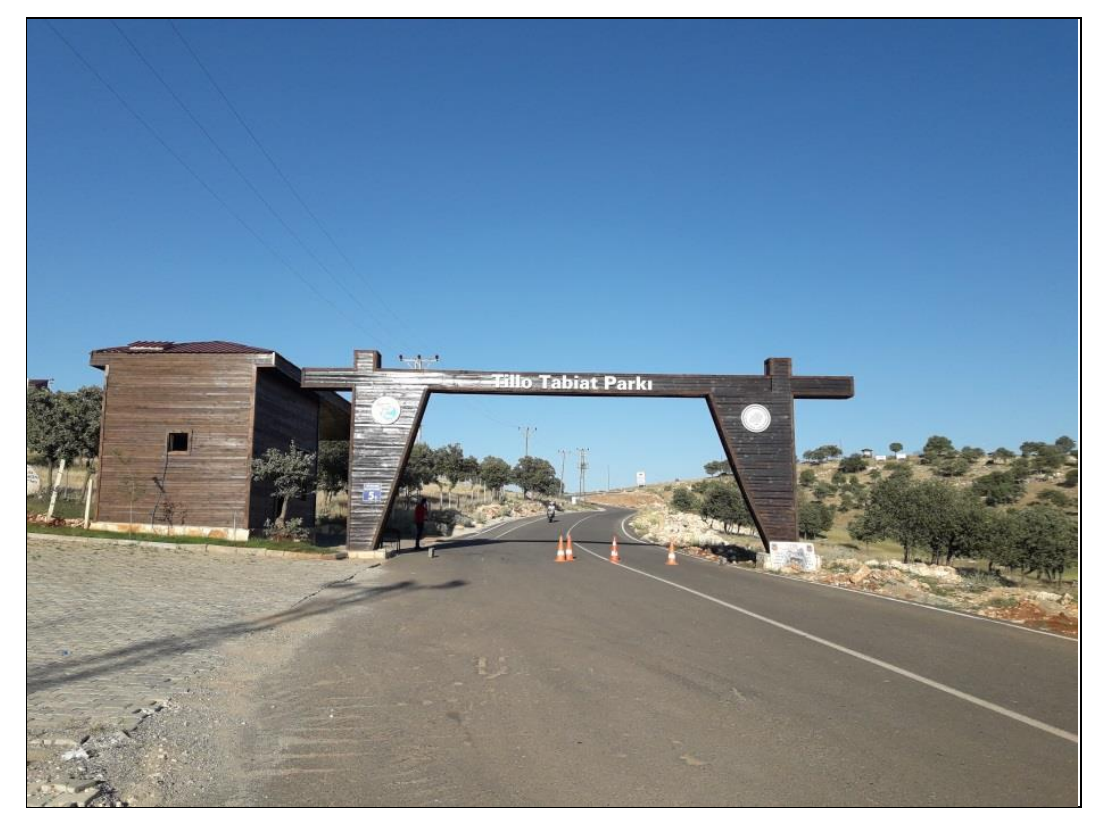

Şekil 3. Tillo Tabiat Parkı Girişi (Orijinal, 2018)

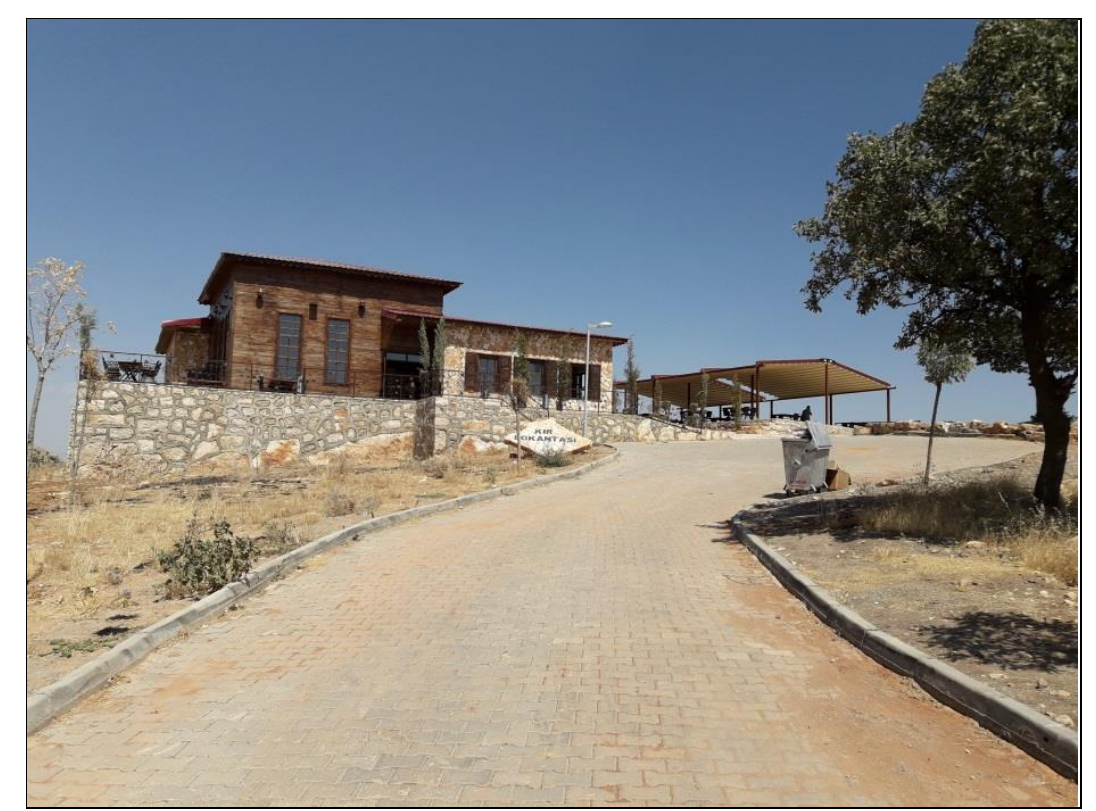

Şekil 4. Tillo Tabiat Parkı'nda yer alan kır lokantası (Orijinal, 2018) 


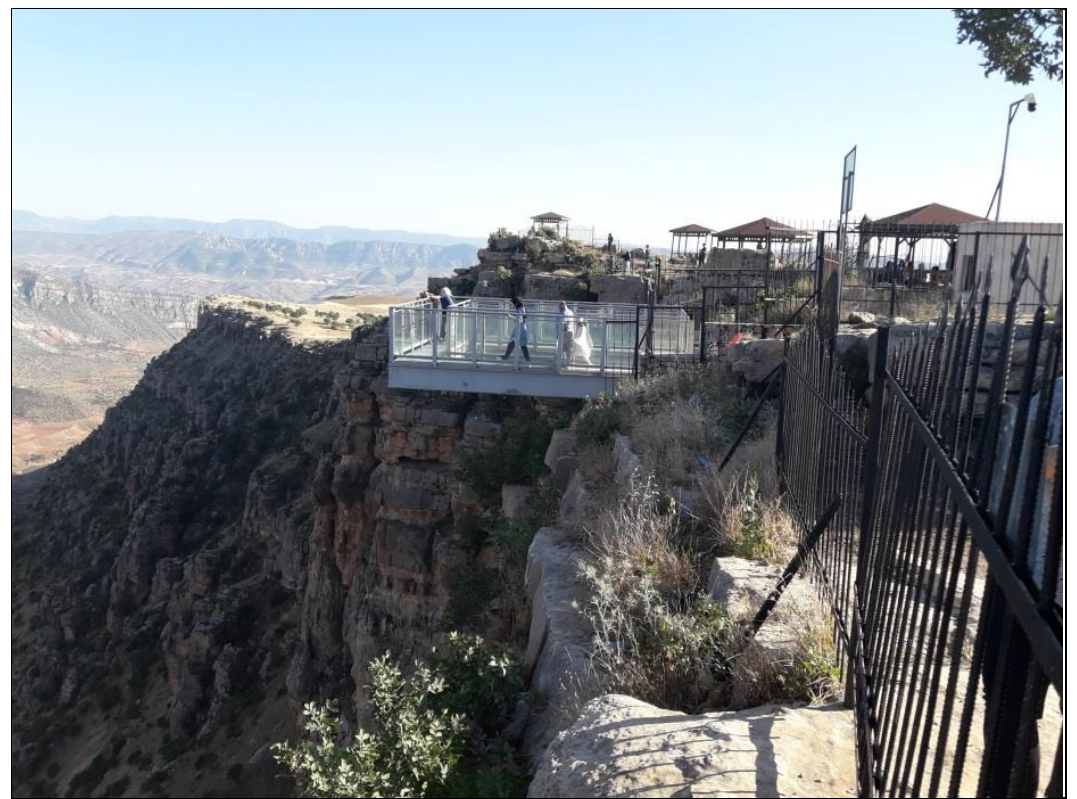

Şekil 5. Tillo Tabiat Parkı cam seyir terası (Orijinal, 2018)

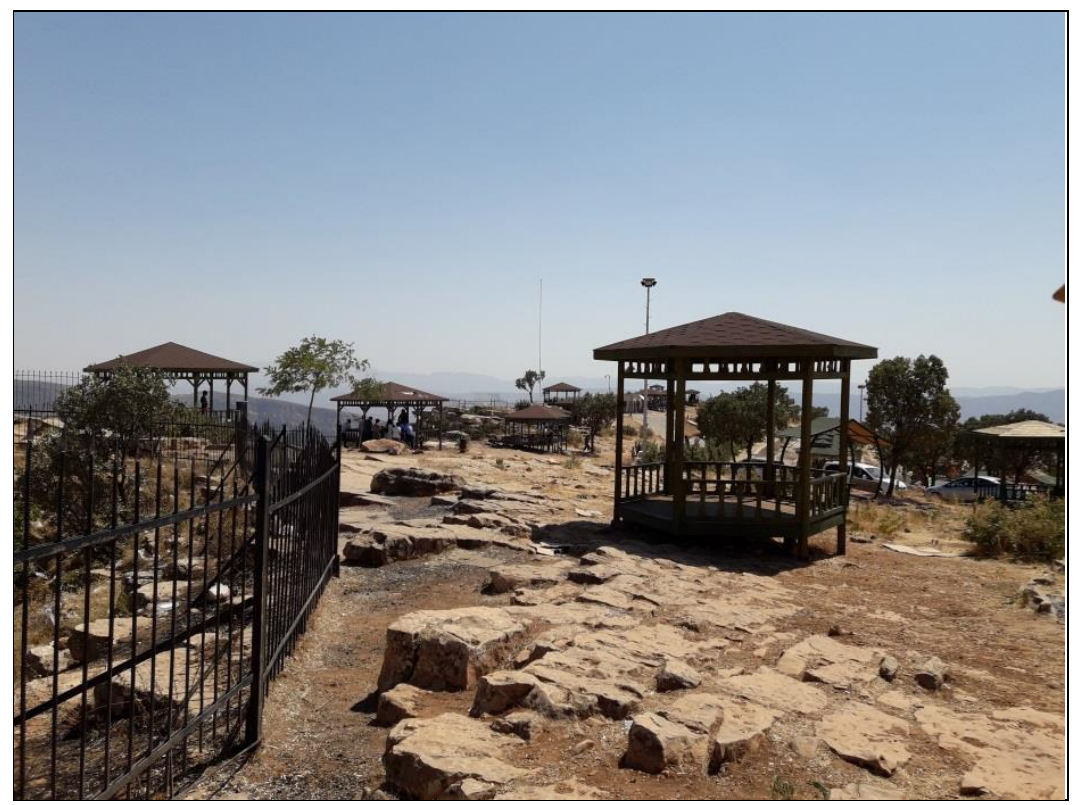

Şekil 6. Tillo Tabiat Parkı oturma birimleri (Orijinal, 2018)

Tillo Tabiat Parkı içerisindeki tek tarihi yapı küçük ölçekteki kale duvarı kalıntısıdır (Altuntaş, 2018).

Tabiat Parkı, Siirt kent merkezine yakınlığı nedeniyle özellikle yöre halkı tarafından günübirlik kullanılmaktadır. Alanda günübirlik kullanıcılar için piknik yapma, fotoğrafçılık, doğa gezisi, kuş gözlemciliği, piknik, dağcılık, yamaç paraşütü gibi imkanlar bulunmaktadır (Altuntaş, 2018).

Çalışmada konuyla ve alanla ilgili yapılan literatür taramalarından, alana yönelik hazırlanan anket sonuçlarından, ilgili kurum ve kuruluşların belgelerinden, T.C. Tarım ve Orman Bakanlığı Doğa Koruma ve Milli Parklar Genel Müdürlüğü’nün hazırladığı haritalardan yararlanılmıştır. Ayrıca yetkili kişilerle ve yöre halkıyla yapılan sözlü görüşmelerden de faydalanılmıştır.

\subsubsection{Metot}

Çalışma üç aşamadan oluşmaktadır. Birinci aşamada konuyla ilgili literatür taramaları yapılarak arazi gözlemleri ile alan analiz edilmiştir. İkinci aşamada ise park kullanıcılarının memnuniyet düzeylerini ölçebilmek amacıyla bir anket çalışması uygulanmış olup anket sonuçları SPSS 15.0 istatistik programı yardımıyla analiz edilmiştir. 
Alan kullanıcıları için hazırlanan anket, \% 95 güven aralığında, 2018 yılı Haziran - Eylül dönemleri arasında tesadüfi yöntemle seçilen 100 kişiye yüz yüze görüşme şeklinde uygulanmıştır. Anket üç bölümden oluşmaktadır. Birinci bölümde katılımcıların alanı tercih nedenleri ve kullanım sıklığına yönelik sorular, ikinci bölümde tabiat parkı ile ilgili memnuniyet düzeylerini ölçmeye ilişkin sorular ve son bölümde ise demografik özelliklere ilişkin sorular yer almaktadır.

Araştırmanın son aşamasında ise elde edilen veriler değerlendirilerek Tillo Tabiat Parkı kullanıcılarının memnuniyet düzeylerine ilişkin sonuçlar ortaya konulmuş ve öneriler geliştirilmiştir.

\section{Bulgular}

\subsection{Ankete Katılanlarmn Demografik Özellikleri}

Anket çalışmasına katılanların \% 48'i kadın, \% 52'si ise erkek olup bu kişiler arasında 30-44 (\%33) ve 45-60 (\%27) yaş aralıklarında olan bireyler çoğunluktadır. Bu kişilere ait cinsiyet, yaş ve eğitim durumları Çizelge 1 'de verilmişstir.

Çizelge 1. Ankete katılanların demografik özellikleri

\begin{tabular}{llllll}
\hline Cinsiyet & Oran (\%) & Yaş Grubu & Oran (\%) & Eğitim Durumu & Oran (\%) \\
\hline Kadın & 48 & 18 'den küçük & 8 & İlkokul & 17 \\
\hline Erkek & 52 & $18-29$ & 20 & Ortaokul & 31 \\
\hline & $30-44$ & 33 & Lise & Yüksekokul/üniversite \\
\hline
\end{tabular}

Deneklerin \% 17'si çiftçi olarak çalışmaktadır. Serbest meslek sahipleri (\% 16) ve memurlar (\%16) ikinci sırada yer alırken işsizler \% 15 oranla üçüncü sırada bulunmaktadır. Daha sonra ev hanımları, emekliler, işçiler ve öğrenciler gelmektedir.

\subsection{Ankete Katılanların Tillo Tabiat Parkı ile İlgili Görüşleri}

Deneklere Tillo Tabiat Parkı'nı neden tercih ettikleri sorulmuştur. Bu soruya deneklerin \% 53'ü hem piknik yapmak hem de manzarayı/doğayı seyretmek cevabını verirken; katılımcıların \% 18'si yalnızca piknik yapmak için alana geldiklerini belirtmişlerdir. Deneklerin en çok tercih ettikleri ay Haziran (\% 25) ayıdır. Eylül (\% 23), Ağustos (\% 18), Ekim (\% 18) ve Temmuz (\% 16) ise tercih edilen diğer aylardır (Şekil 7).
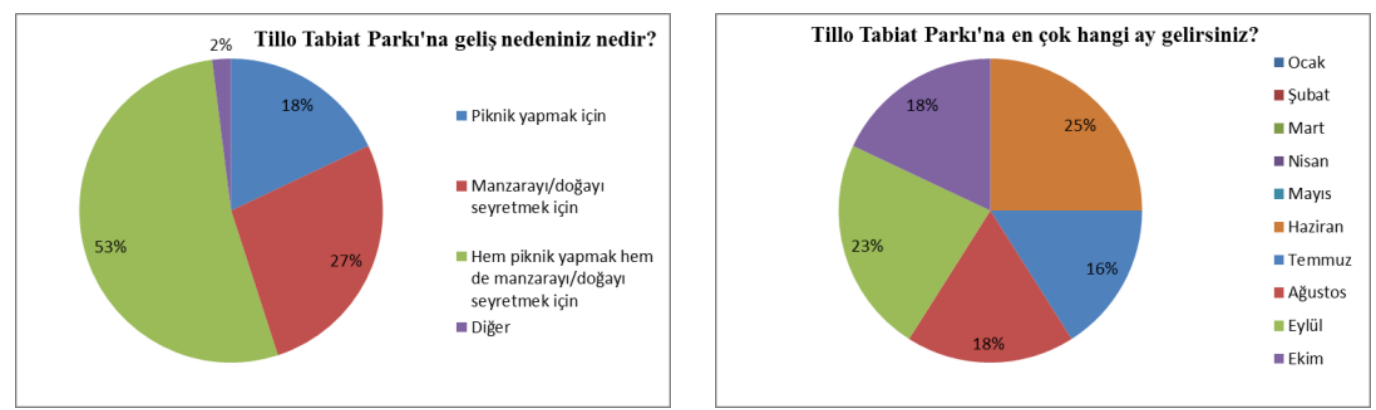

Şekil 7. Katılımcıların alana geliş nedenleri ve tercih ettikleri aylara ilişkin soruya verdikleri cevaplar

Katılımcılar genel olarak hafta sonu (\% 75), öğleden sonra (\% 36) ve akşam saatlerinde ( $\%$ 44) alanı ziyaret etmektedirler. Deneklere alana ne sıklıkla geldikleri de sorulmuştur. Bu soruya ise \% 49 oranında haftada bir cevabı verilmiştir (Şekil 8). 
European Journal of Science and Technology

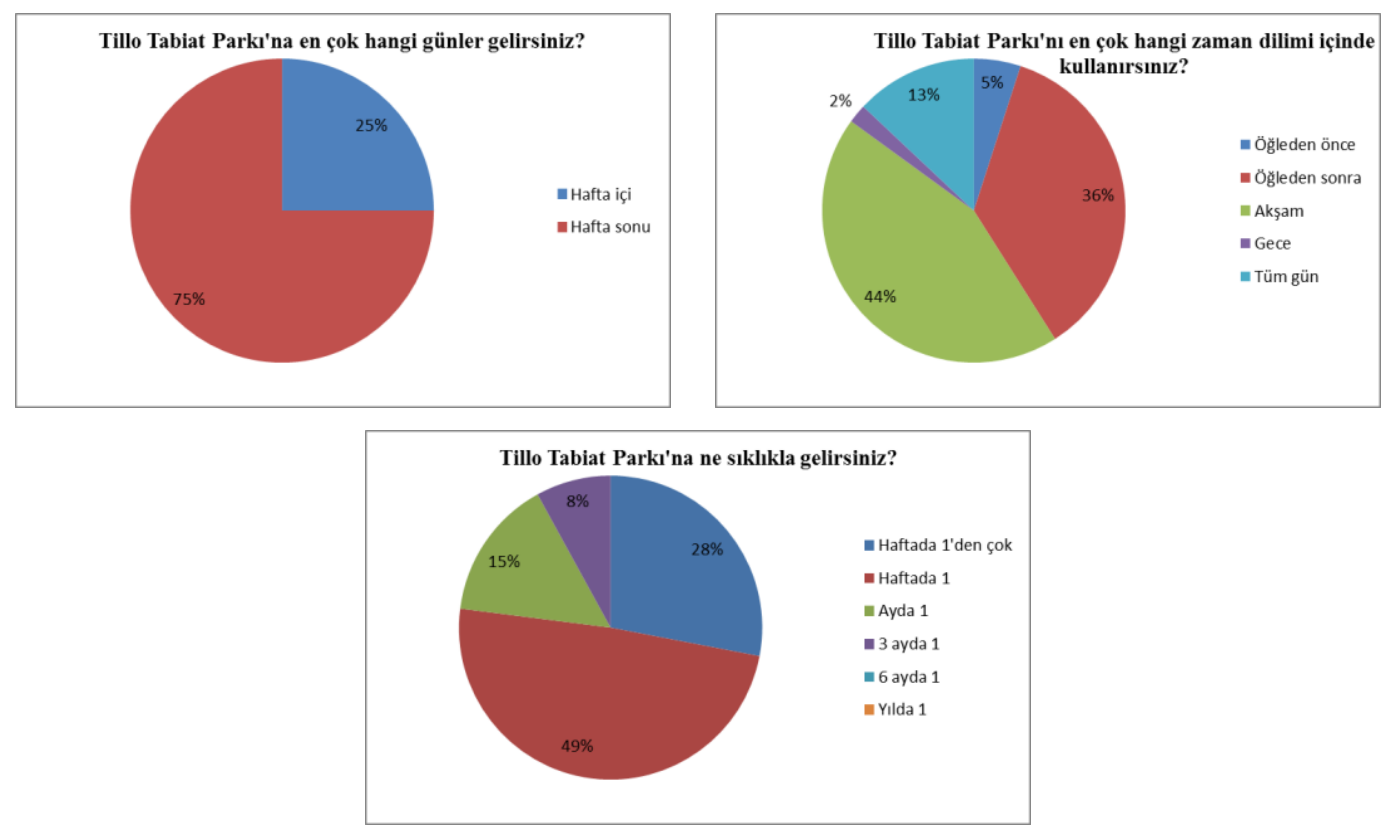

Şekil 8. Katılımcıların alanı en çok kullandıkları gün, zaman dilimi ve gelişsıklıklarına ilişkin verdikleri cevaplar

Katılımcılara alanın en olumlu ve en olumsuz yönlerine ilişsin açık uçlu sorular sorulmuştur. Alanın en olumlu yönleri için piknik yapma imkanı (\% 62) ve alanın manzarası (\% 25) cevapları verilirken; en olumsuz yönler ise bitki örtüsünün yetersizliği (\% 37), gölge alanların azlığı (\% 36) ve ulaşım (toplu taşıma) sıkıntısı (\% 18) olarak belirtilmiştir (Şekil 9).
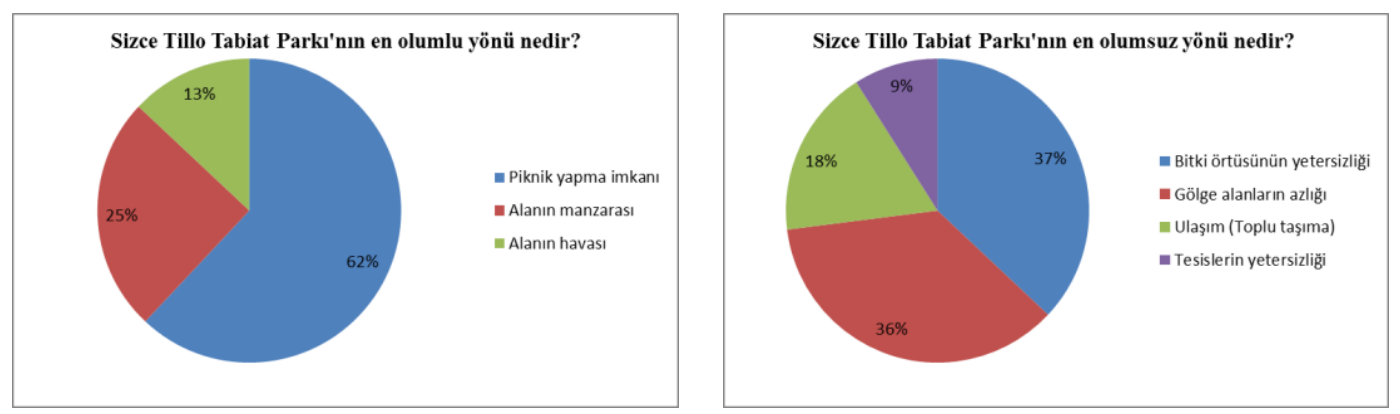

Şekil 9. Katılımcıların alanın en olumlu ve en olumsuz yönlerine ilişkin verdikleri cevaplar

Anket katılımcılarının \%44'ü alandan memnun olduklarını belirtirken; \% 16'sı kararsız olduklarını ve \% 3’ü ise hiç memnun olmadıklarını ifade etmişlerdir. Deneklerin \% 78'i alana tekrar gelebilecekleri ve \% 82'si ise Tillo Tabiat Parkı'nı başkalarına tavsiye edecekleri cevabını vermişlerdir (Şekil 10).
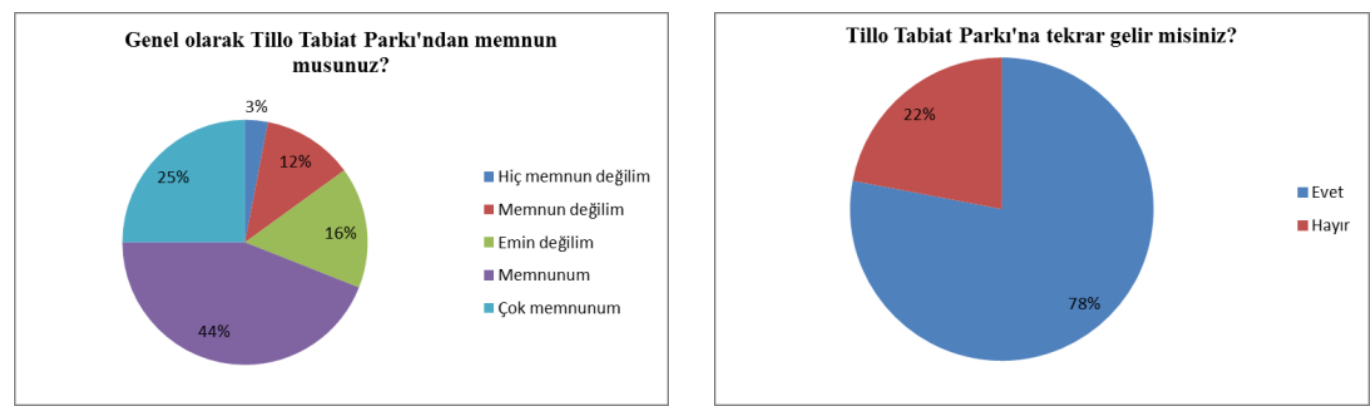


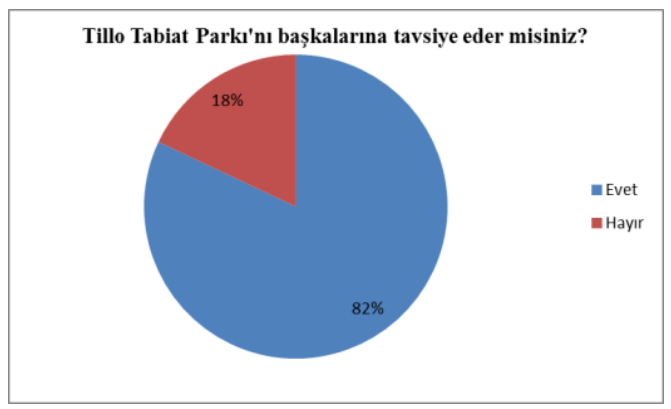

Şekil 10. Katılımcıların alandan memnun olma/olmama ve tavsiye etme/etmeme durumlarına ilişkin verdikleri cevaplar

Verilen cevaplar kendi aralarında çaprazlanarak Ki Kare testi uygulanmıştır. Fakat değişkenler arasında \%1 ve \%5 önem derecelerine göre anlamlı bir ilişki bulunamamıştır. Çalışma sonuçlarına ait grafikler Şekil 7'de verilmiştir.

\section{Sonuç ve Öneriler}

Orta engebeli bir arazi formuna sahip Tillo Tabiat Parkı'nda kültürel değer olarak nitelendirilebilecek tarihi ya da arkeolojik bir alan bulunmamaktadır. Alanda yalnızca küçük ölçekte bir kale duvarı kalıntısı mevcuttur. Sınırları içerisinde olmasa da yakın çevresinde çok sayıda türbe bulunması Tillo Tabiat Parkı'nın kullanımının artmasında önemli bir rol oynamaktadır.

Tillo Tabiat Parkı'na ulaşım yalnızca özel araçlarla sağlanmaktadır. Alana ulaşım sağlayan toplu taşıma araçlarının bulunmaması ulaşımı güçleştirmektedir.

Parkın yakınlarında hava, su ya da gürültü kalitesini azaltacak olumsuz durumların olmaması ve manzarasının güzelliği nedeniyle yöre halkı tarafından tercih edilmektedir.

Bir korunan alanda ziyaretçi yönetim politikalarının belirlenmesi alanın kaynak değerlerinin korunması açısından son derece önemlidir (Akten vd., 2012; Manning vd., 1996; Türker ve Öztürk, 2013; Belkayalı ve Kesimoğlu, 2015; Öztürk vd., 2017). Alan kullanıcılarının memnuniyet dereceleri, beklentilerinin karşılanması ölçüsünde artmaktadır. Bir açık alanda birden çok aktivitenin yapılabilmesi ise kullanıcılar açısından o alanın kullanımında motivasyonu arttırıcı faktörler arasında sayılmaktadır (Fletcher ve Fletcher, 2003; Devesa M. vd., 2010; Öztürk vd., 2017). Tillo Tabiat Parkı'nda piknik dışında fotoğrafçılık, doğa gezisi, kuş gözlemciliği, dağcılık, yamaç paraşütü gibi imkanlarının bulunması, alanın farklı amaçlarla kullanımına da olanak tanımaktadır. Bu imkanlara yönelik geliştirmeler ve iyileştirmeler en kısa zamanda yapılmalı ve parka ilişkin ziyaretçi yönetim planı geliştirilmelidir.

Yapılan bu çalışma ile alanın özellikle yöre halkı tarafından yaz aylarında, hafta sonları ve akşam saatlerinde tercih edildiği belirlenmiştir. Halkın, rekreasyon ihtiyacını karşılama şekli olarak piknik yapmayı tercih etmesi de ulaşılan bir diğer sonuçtur.

Analiz sonuçlarına göre kullanıcıların Tillo Tabiat Parkı'ndan memnuniyet düzeyleri yaklaşık olarak \% 69 olarak bulunmuştur. Bunların \% 25'i çok memnun ve \% 44'ü ise alandan memnun olduklarını belirtmişlerdir. Alanda görülen eksikliklerin giderilmesi ve iyileştirmelerin yapılması memnuniyet düzeyinde artış olabileceğini göstermektedir.

Tillo Tabiat Parkı, Siirt ilinde bulunan tek tabiat parkı ve özellikle yerel halkın kullandığı sınırlı sayıdaki rekreasyon alanından biridir. Bundan dolayı da iyi bir organizasyonla tanıtım ve reklamlarının yapılması, alanla ilgili bilgilendirme toplantılarının gerçekleştirilmesi gerekmektedir.

Alandaki en büyük sıkıntılardan biri, yeterli gölge alanların bulunmamasıdır. Bu da kullanım zamanını sınırlamakta, halkın daha çok akşamları alanı tercih etmesine sebep olmaktadır. Mevcut yapısal gölgelikler yeterli gelmemektedir. Doğru bir bitkisel tasarımla bu alan daha kullanışı bir hale getirilmelidir. Yörede yetişen doğal bitkilerin alanda tercih edilmesi, ekonomik açıdan daha az maliyetli olurken; ekolojik açıdan daha uyumlu bir bitkisel tasarımın gerçekleştirilmesini sağlayacak ve alan kullanıcılarına da daha rahat ve konforlu bir rekreasyon imkanı sunacaktır.

Yöre halkının rekreasyonel faaliyetlere ilgisi ve talebi günden güne artmaktadır. Bununla birlikte mevcut ve yeni düzenlenecek olan rekreasyon alanlarının bu ihtiyaç ve talep doğrultusunda düzenlenmesi, doğru ve dengeli bir koruma kullanım dengesi içerisinde yapılandırılması çok büyük bir önem arz etmektedir. Bunun için de başta peyzaj mimarları olmak üzere farklı meslek disiplininden uzmanların konuya büyük bir özenle yaklaşmaları gerekmektedir. Ayrıca bu tür çalışmalara halkın katılımının sağlanmasıyla, alanın daha iyi bir şekilde tanıtılarak korunmasının ve kullanılmasının sağlanacağı da unutulmamalıdır.

\section{Kaynakça}

Akten, M. (2003). Isparta İlindeki Bazı Rekreasyon Alanlarının Mevcut Potansiyellerinin Belirlenmesi. Süleyman Demirel Üniversitesi Orman Fakültesi Dergisi, Seri: A, Say1: 2, 115- 132 s., ISSN: 1302-7085, Isparta.

Akten, S., Gül, A., Akten, M. (2012). Korunan Doğal Alanlarda Kullanılabilecek Ziyaretçi Yönetim Modelleri ve Karşılaştırılması. SDÜ Orman Fakültesi Dergisi, Sayı: 13(1): 57-65, Isparta. 
Altuntaş, A. (2018). Doğal Alanların Korunması: Tillo Tabiat Parkı Örneği. Dicle Üniversitesi I. Uluslararası Mimarlık Sempozyumu, ISBN: 978-605-9504-17-1, 310-320 s, Diyarbakir.

Anonim, (1983). $2873 \quad$ Sayll Milli Parklar Kanunu. $\quad$ Resmi Gazete, Sayı 18132. $\begin{array}{lcc}\text { http://www.mevzuat.gov.tr/MevzuatMetin/1.5.2873.pdf (Erişim tarihi: 15.08.2018). } & & \\ \text { (1986). Milli } & \text { Parklar }\end{array}$

$\begin{array}{lll}\text { Anonim. } & \text { (1986). Milli } & \text { Parklar } \\ \text { http://mevzuat.basbakanlik.gov.tr/Metin.Aspx?MevzuatKod=7.5.5413\&Mevzuatlliski=0\&source }\end{array}$ 15.08.2018).

Anonim, (2013). Mesire Yerleri Yönetmeliği. Resmi Gazete, Sayı: 28578. http://www.resmigazete.gov.tr/eskiler/2013/03/201303059.htm (Erişim tarihi: 15.08.2018).

Anonim, (2015). Tillo Tabiat Parkı Gelişme Planı. T.C. Orman ve Su İşleri Bakanlığı Doğa Koruma ve Milli Parklar Genel Müdürlüğü, Siirt Şube Müdürlüğü, 125 s., Siirt.

Belkayalı, N, Kesimoğlu, M.D. (2015). The Stakeholders' Point of View About the Impact of Recreational and Tourism Activities on Natural Protected Area: A Case Study From Kure Mountains National Park, Turkey. Biotechnology \& Biotechnological Equipment, 29(6), 1092-1103.

Devesa, M., Laguna, M., Palacios, A. (2010). The Role of Motivation in visitor satisfaction: Empiricial Evidence in Rural Tourism. Tourism Management, 31 (4): 547-552.

Doğa Koruma ve Milli Parklar Genel Müdürlüğü, (2018). Türkiye'nin Korunan Alanları. Ankara.

Fletcher, D., Feltcher, H. (2003). Manageable Predictors of Park Visitor Satisfaction: Maintenance and Personnel. Journal of Park and Recreation Administration, 21(1): 21-37.

Kurum, E., Odabaş, A., (1991). Ankara Kenti İçin Bir Rekreasyon Potansiyeli Beynam Ormanı” “2000’li Yıllar İçin Ankara Kentinin Açık ve Yeşil Alan Sistemi Ne Olmalıdır? Peyzaj Mimarlı̆̆ı Dergisi, Sayı: 91-2, Ankara.

Manning, R., Lime, D., Hof, M. (1996). Social Carrying Capacity of Natural Areas: Theory and Application in the US National Parks. Natural Areas Journal, 16 (2): 118-127.

Öztürk, S., Umdu, D.Ç., Pişkin, Y., Hüsam, A. (2017). Ulugöl Tabiat Parkı Ziyaretçi Memnuniyeti. Karabük Üniversitesi Sosyal Bilimler Enstitüsü Dergisi, Özel Sayı: 3, 160-167 s.

TÜİK (Türkiye İstatistik Kurumu), (2017). Siirt ili nüfus verileri. https://biruni.tuik.gov.tr/medas/?kn=95\&locale=tr (Erişim tarihi: 15.08.2018).

$$
\text { Dil Kurumu, }
$$

(2018).

Rekreasyon. http://www.tdk.gov.tr/index.php?option=com_gts\&arama=gts\&guid=TDK.GTS.5b73e29c353e07.03832022 (Erişim tarihi: 15.08.2018).

Türker, N., Öztürk, S. (2013). Perceptions of Residents Towards The Impacts of Tourism in the Küre Mountains National Park, International of Journal Business and Social $\quad$ Science, 45-56.

Yılmaz, H., Karaşah, B., Erdoğan Yüksel, E., (2009). Gülez Yöntemine Göre Kafkasör Kent Ormanının Rekreasyonel Potansiyelinin Değerlendirilmesi. Artvin Çoruh Üniversitesi Orman Fakültesi Dergisi, Say1: 10(1), 53-61 s., Artvin. 